\title{
Constitutional functions and institutional responsibility: a functional analysis of the UK constitution
}

\author{
Thomas Horsley ${ }^{\star \dagger}$ (D) \\ University of Liverpool, Liverpool, UK \\ *Author e-mail: thomas.horsley@liverpool.ac.uk
}

(Accepted 6 May 2021)

\begin{abstract}
This paper advances a functional analysis of the UK constitution. It explores how the UK constitution discharges three minimum 'constituting', 'legitimating' and 'limiting' functions that citizens living in modern liberal democracies may legitimately expect all constitutions - irrespective of form - to perform. This functional enquiry breaks with dominant trends in the legal scholarship that remain focused on theorising the constitution's underlying political or legal nature or, likewise, identifying its ultimate source of authority. In addition to offering a richer descriptive account of constitutional practice, this paper identifies, normatively, an institutional responsibility for Parliament to discharge the UK constitution's three minimum functions. Recognising that institutional responsibility unlocks fresh insights into two constitutional conundrums: the legitimacy of judicial review and the status of 'constitutional statutes'. At the same time, it also exposes deficiencies and tensions in relation to the quality of Parliament's institutional performance on matters of minimum constitutional functioning.
\end{abstract}

Keywords: constitutional functions; UK constitution; institutional responsibility; parliamentary sovereignty; rule of law; judicial review

\section{Introduction}

A perennial issue animates contemporary study of the UK constitution; namely, discussion of that constitution's underlying political or legal character. Whether theorising the constitution holistically, or attempting to rationalise specific constitutional developments, legal scholars offer competing principled-based accounts of the UK constitution that are tied, ultimately, to varying models of political or legal constitutionalism. ${ }^{1}$ Much of this scholarship continues, in the positivist tradition, to focus (implicitly, if not explicitly) on the identification and defence of the UK constitution's ultimate source of authority. ${ }^{2}$ For those who prioritise the virtues of political constitutionalism, the doctrine of parliamentary sovereignty retains that crowning status. ${ }^{3}$ For those more inclined

${ }^{\dagger}$ I wish to thank John Bell, Matthew Gibson, Mike Gordon and Alison Young and for their generous feedback on earlier versions of this paper. I am also grateful to the anonymous reviewers for their detailed and insightful comments. All errors remain my own.

${ }^{1}$ Contrast eg JA Griffith 'The political constitution' (1979) Modern Law Review 1, A Tompkins Our Republican Constitution (Oxford: Hart Publishing, 2005) and R Bellamy Political Constitutionalism: A Republican Defence of the Constitutionality of Democracy (Cambridge: Cambridge University Press, 2007) with eg TRS Allan Law, Liberty, and Justice: The Legal Foundations of British Constitutionalism (Oxford: Clarendon Press, 1993) and J Laws 'Law and democracy' (1995) Public Law 72.

${ }^{2}$ See J Laws The Common Law Constitution (Cambridge: Cambridge University Press, 2013) p 28.

${ }^{3}$ Eg AL Young Parliamentary Sovereignty and the Human Rights Act (Oxford: Oxford University Press, 2009); J Goldsworthy Parliamentary Sovereignty: Contemporary Debates (Cambridge: Cambridge University Press, 2010); and M Gordon Parliamentary Sovereignty in the UK Constitution: Process, Politics and Democracy (Oxford: Hart Publishing, 2015).

(C) The Author(s), 2021. Published by Cambridge University Press on behalf of The Society of Legal Scholars. This is an Open Access article, distributed under the terms of the Creative Commons Attribution licence (http://creativecommons.org/licenses/by/4.0/), which permits unrestricted re-use, distribution, and reproduction in any medium, provided the original work is properly cited. 
to legal constitutionalism, the common law is now the UK constitution's 'ultimate controlling factor'. 4

This paper advances an alternative, functional approach to the study of the UK constitution - one which centres on the scrutiny of constitutional functions and, in doing so, identifies and legitimates an institutional responsibility to safeguard those functions. ${ }^{5}$ Its core aim is to assess - both descriptively and normatively - how the UK constitution discharges three constitutional functions that citizens living in modern liberal democracies may legitimately expect all constitutions - irrespective of form - to perform. Section 1 outlines these functions. It argues that, at a minimum, liberal constitutions should, first, constitute the state and the institutions of government; secondly, legitimate the exercise of public power; and, thirdly, limit the power of the state to safeguard citizens from arbitrary rule. ${ }^{6}$ It is important to stress that this paper does not claim that these are the only functions that the UK constitution performs (or should perform). The fundamental nature of the three functions should also be emphasised: 'minimum' does not, in any sense, denote insignificant. The identification of these three functions as 'minimum constitutional requirements' is tied to an understanding of constitutions as instruments of democratic self-government in the liberal tradition. It serves an important structural purpose, establishing a benchmark to scrutinise descriptively and normatively the performance of the UK constitution as the foundation of a liberal state.

Next, section 2 explores how the UK constitution presently discharges its three 'constituting', 'legitimating' and 'limiting' functions. At the level of constitutional practice, this section reveals that the UK constitution now relies on a highly developed statutory framework to meet these three minimum demands of the liberal constitution. ${ }^{7}$ Hitherto, the scholarly focus on questions of ultimate authority or, likewise, the dynamics of political versus legal constitutionalism has tended to divert attention away from analysing the extent and depth of this established statutory framework. This paper's review of constitutional practice redresses that imbalance. In so doing, it also signals to advocates of codification that the UK constitution already rests on a comprehensive - albeit not formally entrenched - statutory framework that speaks directly to all three minimum constitutional functions.

However, this paper aims to do more than simply map UK constitutional practice. Rather, it is concerned, additionally, with the attribution of institutional responsibility to deliver minimum constitutional functions. Accordingly, this paper identifies and legitimates a framework of institutional responsibility which operates to ensure that, as the basis of a modern liberal state, the UK constitution discharges its three fundamental constituting, legitimating and limiting functions. That framework attributes to Parliament an important institutional responsibility to legislate to ensure the satisfaction of the minimum demands of the liberal constitution. In abstract terms, that conclusion is unlikely to unsettle legal scholars who already recognise Parliament's central role under the UK constitution. Nor, as this paper demonstrates (in section 2), is it out of step with established constitutional practice. But it raises a crucial normative question nonetheless: on what basis should Parliament be required to assume responsibility on matters of minimum constitutional functioning? It also poses a conceptual challenge: how should we theorise the relationship between that institutional responsibility and the doctrine of parliamentary sovereignty?

\footnotetext{
${ }^{4}$ Lord Hope in Jackson v Attorney General [2005] UKHL 56, [2006] 1 AC 262 at [107]. See eg Allan, above n 1; Laws, above n 1; S Lakin 'Debunking the idea of parliamentary sovereignty: the controlling factor of legality in the British constitution' (2008) 28 OJLS 709; and TRS Allan The Sovereignty of Law: Freedom, Constitution, and Common Law (Oxford: Oxford University Press, 2013).

${ }^{5}$ On functionalism and its intellectual origins in public law, see M Loughlin 'The functionalist style in public law' (2005) 55 (3) Toronto Law Journal 361.

${ }^{6}$ See generally J Bryce Constitutions (Oxford: Oxford University Press, 1905) p vii; C Mcllwain Constitutionalism: Ancient and Modern (New York: Liberty, 1947); KC Wheare Modern Constitutions (Oxford: Oxford University Press, 1975) p 1. See also House of Lords Constitution Committee First Report of 2001-2 HL Paper 11, para 20.

${ }^{7}$ See also V Bogdanor The New British Constitution (Oxford: Hart Publishing, 2009) and A Psygkas 'The United Kingdom's statutory constitution' (2020) 40 OJLS 449.
} 
In response to the former question, section 3 argues that Parliament's institutional responsibility follows for three reasons: institutional capacity, democratic legitimation and affinity with the doctrine of parliamentary sovereignty. It then outlines two important findings that attach to the recognition of that responsibility: the establishment of a positive obligation for Parliament to legislate to discharge its institutional responsibility, and a corresponding role for courts to intervene in instances of institutional failure. In reply to the latter question, section 4 concludes that Parliament's institutional responsibility to satisfy the constitution's minimum constituting, legitimating and limiting functions operates as an external normative restraint on its legislative supremacy under the doctrine of parliamentary sovereignty.

Ultimately, the functional approach advanced in this paper establishes a powerful framework to scrutinise Parliament's exercise of its legislative supremacy, at least in relation to matters of minimum constitutional functioning. In so doing, it breaks with the dominant scholarly focus on considerations of ultimate authority or, likewise, the study of the UK constitution as a paragon of political or legal constitutionalism. Rather than fixating on such considerations, the functional approach directs legal scholars to interrogate the nature and quality of the product that is being constructed: the liberal constitution.

Section 5 explores the practical implications of this paper's functional approach. It argues that the institutional responsibility framework makes three distinct contributions to our understanding of the UK constitution. First, it enables us to make better sense of the emerging jurisprudence gesturing at the judicial review of primary legislation; ${ }^{8}$ secondly, it offers a richer and more coherent account of the place of 'constitutional statutes' within the UK constitution; and thirdly, it diagnoses specific deficiencies in Parliament's legislative output on matters of minimum constitutional functioning. The first and second contributions unlock fresh perspectives on two constitutional conundrums; the third moves beyond existing debates to highlight new instances of constitutional tension. Examples of such tension include Parliament's failure to legislate to discipline important prerogative powers (including, notably, the prerogative power to prorogue Parliament) ${ }^{9}$ as well as its longstanding efforts, when legislating on constitutional matters, to prioritise protecting the integrity of its legislative supremacy over considerations of minimum constitutional functioning.

\section{On functionalism and minimum constitutional functions in liberal states}

The functional approach (or 'style ${ }^{10}$ ) defends a purposeful understanding of public law that emphasises the specific ends to which state power ought to be directed. For Jennings, Laski and others writing on the UK constitution in the early to mid-twentieth century, this more purposeful conceptualisation of public law was developed to challenge classical liberal perspectives on state power. ${ }^{11}$ Functionalism was a response to modernisation - an attempt to theorise state power as an instrument to advance positive liberty within increasingly complex and rapidly changing societies.

This paper's revival of the functionalist approach continues the earlier tradition of decoupling state power from sovereignty-based concerns about identifying ultimate political authority or, likewise, arguing about the legal or political nature of the UK constitution. ${ }^{12}$ However, at the substantive level, it adopts a different approach to the definition of functional purposes. Rather than follow

\footnotetext{
${ }^{8}$ Eg see Lord Steyn in Jackson v Attorney General [2005] UKHL 56, [2006] 1 AC 262 at [102]. See, thereafter, Lord Hope in AXA General Insurance Ltd and Others $v$ The Lord Advocate and Others (Scotland) [2011] UKSC 46, [2012] 1 AC 868 at [50]-[51]. See also Lord Mance and Lord Neuberger in HS2 Action Alliance Ltd $v$ Secretary of State for Transport [2014] UKSC 3, [2014] 1 WLR 324 at [207] and Lord Carnwath in $R$ (on the application of Privacy International) $v$ Investigatory Powers Tribunal and Others [2019] UKSC 22, [2019] 2 WLR 1219 at [123] and at [131].

${ }^{9} R$ (on the application of Miller) $v$ The Prime Minister [2019] UKSC 41, [2019] WLR 589.

${ }^{10}$ Loughlin, above n 5.

${ }^{11}$ Ibid, at 362. See eg H J Laski A Grammar of Politics (London: Allen and Unwin, 1930). See also L Duguit Law in the Modem State (London: Allen \& Unwin, 1921), cited in Loughlin, above n 5, at 370-371.

${ }^{12}$ See also M Loughlin The Idea of Public Law (Oxford: Oxford University Press, 2004), who theorises public law functionally as an 'activity of governing'.
} 
established traditions historically pioneered by those associated with the London School of Economics, this paper reconnects functionalism with the liberal perspectives on constitutions that, in the UK at least, the functional approach was originally developed to challenge. This realignment of functionalism with considerations of minimum constitutional functioning in the liberal tradition furnishes this paper's enquiry with a suitable framework within which to reflect descriptively and normatively on questions of constitutional performance. It remains, of course, open to others to identify and defend alternative normative frameworks to animate their own functional critiques of the UK constitution. ${ }^{13}$

\section{(a) Three minimum constitutional functions}

Within liberal states, constitutions perform three minimum functions: they constitute the state and the institutions of government; legitimate public power; and limit state power in order to protect citizens from arbitrary rule. The identification of these three constitutional functions as minimum requirements draws expressly on fundamental principles of democratic self-rule in the classical liberal tradition. In line with that tradition, citizens' consent to state authority is directly associated with, and ultimately dependent upon, the establishment of structures, institutions and principles that function to constitute, legitimate and limit the exercise of that authority as a means to safeguard individual liberty.

The first requirement, the constituting function, is the most basic of the three minimum functions. Constitutions exist, first and foremost, to establish the state and, typically in modern democracies, its three distinct branches of government: the legislature, the executive and the judiciary. As Grimm argues, the establishment of the state and the institutions of government is 'fulfilled by the very existence of the constitution. It is what it exists for: creating... public authority that did not previously exist or did not exist in the same form'. ${ }^{14}$

In addition to establishing the state and the basic institutions of government, constitutions perform a second, important legitimating function within liberal states. They aspire to link the establishment of the state with the people or, more abstractly, with conceptions of popular sovereignty. The United States Constitution famously opens with a direct appeal to the will of US citizens ('We the people of the United States...'). Other constitutional settlements express similar sentiments. The German Basic Law, for instance, references in its preamble the role of the 'German people, in the exercise of their constituent power' in the adoption of that instrument with effect for 'the entire German people'.

The link between the constitution and the people is, of course, largely a legal fiction, but an important one, nonetheless. It functions as both an antecedent and ongoing claim to legitimate the establishment of the state, along with the exercise of public power over individual citizens within the state. In the words of Justice Marshall with reference to the US Constitution, constitutions classically proclaim that,

government proceeds directly from the people; is 'ordained and established' in the name of the people... Its powers are granted by them and are to be exercised directly on them, and for their benefit... It is the government of all; its powers are delegated by all; it represents all; and acts for all. $^{15}$

The requirement to constitute and legitimate the state and its coercive authority over citizens is the original liberal concern. It draws on ideas of protective democracy according to which democratic selfrule is only sustainable on the basis of citizens' consent to state authority as an instrumental means to secure their liberty. ${ }^{16}$ Locke's great contribution to liberal theory was to expand this formative concern

\footnotetext{
${ }^{13}$ Liberal constitutions may pursue a range of additional functions, such as political integration and transitional justice. On 'positive' constitutional functions see NW Barber The Principles of Constitutionalism (Oxford: Oxford University Press, 2018) pp 2-6.

${ }^{14} \mathrm{D}$ Grimm 'Integration by constitution' (2005) 3 ICON 193 at 195.

${ }^{15}$ McCulloch $v$ Maryland (1819) 17 US (4 Wheaton) 316 at [404]-[405].

${ }^{16}$ See generally D Held Models of Democracy (Cambridge: Polity Press, $3^{\text {rd }}$ edn, 2006) pp 55-95 and TL Pangle and TW Burns The Key Texts of Political Philosophy: An Introduction (Cambridge: Cambridge University Press, 2015) pp 246-275.
} 
with the constitution and legitimation of state authority by introducing a third minimum function. ${ }^{17}$ In the Lockean tradition, to safeguard individual liberty, liberal constitutions must not simply constitute and legitimate government power, but equally also limit its exercise. ${ }^{18}$ Constitutions must guarantee that government in the name of the people means limited government, free from the dangers of arbitrary rule. Constitutional government, as Wheare argues, denotes,

government according to rule as opposed to arbitrary government; it means government limited by the terms of a Constitution, not government limited only by the desires and capacities of those who exercise power. ${ }^{19}$

Constitutions limit the exercise of government power in a range of different ways. Locke's formative thesis took a rather limited view of the mechanisms necessary to ensure 'good government' - subsequent writers, notably Montesquieu and de Tocqueville, expanded horizons. It is now widely recognised that constitutions aspire to protect citizens from arbitrary rule by maintaining a relatively clear separation of powers to avoid concentrations of authority; ${ }^{20}$ by upholding the rule of law and the protection of fundamental rights; ${ }^{21}$ and by establishing legal and/or political mechanisms to scrutinise the exercise of both administrative and legislative power. ${ }^{22}$ This is true regardless of whether or not constitutions are formally codified. Contemporary constitutions invariably adopt distinct solutions to give specific effect to the preceding cornerstones of the liberal constitution. And there are, as section 2 will further explicate, important distinctions in approach between states that have adopted written constitutions and those, such as the UK, that have not. Yet, differentiating features aside, the underlying functional concern - protecting citizens from arbitrary rule - remains the same within all modern liberal democracies regardless of constitutional form. ${ }^{23}$

\section{Constitutional practice: how does the UK Constitution discharge its three minimum constitutional functions?}

The UK constitution appears strikingly atypical in comparison with those of most other liberal democracies, on account of its uncodified character and distinctive keystone organising principle: the doctrine of parliamentary sovereignty. ${ }^{24}$ In its classic exposition, that doctrine is taken to outline Parliament's competence to make and unmake any law it pleases and, further, recognises that no other body is competent to set aside Acts of Parliament. ${ }^{25}$ As a prelude to the normative argument on institutional responsibility (section 3, below), this section explores how the UK constitution, with its doctrine of parliamentary sovereignty, meets the challenge of discharging the three minimum functions that citizens may legitimately expect all constitutions to perform within liberal states, including the UK. Legal scholars rarely engage with this question directly, reflecting, again, their embedded focus on the identification and defence of final constitutional authority. This section concludes that, as

\footnotetext{
${ }^{17}$ See J Locke Two Treatise of Government and A Letter Concerning Toleration (Oxford: Oxford University Press, 2016).

${ }^{18}$ See also Montesquieu in AM Choler et al (eds) Montesquieu: The Spirit of the Laws (Cambridge: Cambridge University Press, 1989) p 155. For Barber, this is the core of 'negative constitutionalism'. See Barber, above n 13, pp 2-6.

${ }^{19}$ Wheare, above n 6, p 37.

${ }^{20}$ See generally eg Montesquieu in Choler et al, above n 18, pp 156-157.

${ }^{21}$ Eg United States Bill of Rights 1789 and the German Basic Law 1949 (as amended). On the rule of law see J Jowell 'The rule of law' in J Jowell and C O'Cinneide (eds) The Changing Constitution (Oxford: Oxford University Press, $9^{\text {th }}$ edn, 2019).

${ }^{22}$ See eg Kelsen's classic study 'Judicial review of legislation: a comparative study of the Austrian and the American Constitution' (1942) 4 The Journal of Politics 183 and, more recently, D Lustig and JHH Weiler 'Judicial review in the contemporary world - retrospective and prospective' (2018) 16 ICON 315.

${ }^{23}$ See eg Lord Hoffmann in $R v$ Secretary of State for the Home Department, ex $p$ Simms [2003] 2 AC 115 at [131]. See also eg European Commission for Democracy through Law (Venice Commission) Report on the Rule of Law CDL-AD (2011).

${ }^{24}$ AV Dicey An Introduction to the Study of the Law of the Constitution (London: MacMillan, 1967) p 70. See also eg $R$ (on the application of Miller) $v$ The Prime Minister and Cherry $v$ Advocate General for Scotland [2019] UKSC 41, [2019] WLR 589 at [41]. On parliamentary sovereignty as a principle of constitutional organisation, see also Gordon, above n 3 , p 28.

${ }^{25}$ Dicey, above n 24, pp 39-40. See also Blackstone The Oxford Edition of Blackstone's: Commentaries on the Laws of England (Oxford: Oxford University Press, 2016) p 66.
} 
a matter of constitutional practice, the UK constitution now rests, to a great extent, on a highly developed statutory framework to meet the minimum demands of the liberal constitution.

\section{(a) Parliamentary sovereignty and minimum constitutional functions}

The first conclusion to draw when scrutinising the performance of minimum constitutional functions under the UK constitution is uncontroversial - yet it is fundamental, nonetheless. It is simply to recognise that, as a statement of Parliament's legislative supremacy, the doctrine of parliamentary sovereignty contributes very little to the discharging of the liberal constitution's three minimum functions. It cannot be said, therefore, to operate in proxy for a formally codified constitution. With regard, first, to the constituting function, the doctrine does not establish the state or its basic institutions. This includes the institution of Parliament itself. As a statement on legislative supremacy, the doctrine references only the legal force of Acts of Parliament within the UK. ${ }^{26}$

The doctrine of parliamentary sovereignty also makes only a limited contribution to the second, legitimating function. Most strikingly, perhaps, there is no intrinsic normative connection between the recognition of Parliament's legislative supremacy and any conception of popular sovereignty. Expressed as a legal rule, the doctrine simply outlines that Parliament - an institution that the doctrine does not itself formally establish - enjoys legislative supremacy whenever its commands are expressed in a specific form (primary legislation). Parliament's supreme law-making power need not only be exercised by, or in the name of, the people. Its doing so may reflect historical experience and, accordingly, be readily assumed. ${ }^{27}$ But there is, fundamentally, nothing to preclude the linking of Parliament's legislative supremacy with a system of aristocratic or even autocratic rule. ${ }^{28}$ Indeed, the doctrine survived well into the twentieth century tied to the former model and, in the eyes of some, remains today insufficiently representative in democratic terms.

To satisfy the legitimating requirement, a sufficiently robust connection to popular sovereignty must be grafted onto the doctrine of parliamentary sovereignty. At times, even Dicey himself appeared to sidestep this move. Indeed, his account of the doctrine in An Introduction to the Study of the Law of the Constitution openly rejected the agency approach to parliamentary sovereignty; in other words, the notion that Parliament, through a system of representative democracy, functioned as the agent of the UK electorate. ${ }^{29}$ Discussing the Septennial Act 1716 - by which Parliament prolonged its own existence - Dicey was clear in his view that Parliament's legislative supremacy exists independently of the electorate. As he put it,

Parliament is neither the agent of the electors nor in any sense a trustee for its constituents. It is legally the sovereign legislative power in the state. ${ }^{30}$

In later writings, Dicey came to identify sovereignty with public opinion at large, rather than Parliament itself - an intellectual progression that underpinned his defence of referenda. ${ }^{31}$ In contrast, contemporary legal scholars now make unequivocal appeals to popular sovereignty in an effort to bolster parliamentary sovereignty's legitimating credentials. According to Jowell, for example, 'the legitimacy of parliamentary sovereignty rests upon Parliament's representative and accountable features' ${ }^{32}$

\footnotetext{
${ }^{26}$ See here also Young, above n 3, pp 15-22, who frames the doctrine as one of 'continuing parliamentary legislative supremacy'.

${ }^{27}$ Dicey certainly made that an assumption. See P Craig 'Dicey: unitary, self-correcting democracy and public law' (1990) 106 Law Quarterly Review 105 at 108.

${ }^{28}$ Bagehot, for instance, railed against the extension of the popular franchise as an 'evil of the first magnitude' See W Bagehot The English Constitution, cited in Craig, above n 27, at 133.

${ }^{29}$ Elsewhere, however, Dicey engaged more fully with the agency approach. See JWF Allison (ed) The Oxford Edition of Dicey, vol 2 (Oxford: Oxford University Press, 2013) pp 218-219. I am grateful to Dr Allison for this point.

${ }^{30}$ Dicey, above n 24, p 48.

${ }^{31}$ See AV Dicey 'Will the form of parliamentary government be permanent? (1899) 13 Harvard Law Review 67 and AV Dicey 'Ought the referendum to be introduced into England?' (1890) 57 Contemporary Review 489.

${ }^{32} \mathrm{~J}$ Jowell 'Parliamentary sovereignty under the new constitutional hypothesis' (2006) PL 562 at 572.
} 
Similarly, Gordon argues that parliamentary sovereignty's core virtue is its promotion of the 'constitutional primacy of (majoritarian) decision-making' within a liberal democracy. ${ }^{33}$

Finally, with respect to the UK constitution's third, limiting function, we should acknowledge that the doctrine of parliamentary sovereignty makes a much stronger contribution, principally with respect to the separation of powers. That doctrine transmits a powerful signal to other constitutional actors (notably courts) regarding the subjugation of all political authority to the legal force of Acts of Parliament. ${ }^{34}$ At the same time, however, the doctrine of parliamentary sovereignty tells us nothing about the substantive restraints imposed on government power. It does not, for instance, introduce a framework of basic rights, or establish a system of judicial review that operates to subjugate the exercise of legislative and administrative power to those rights. As a statement on the legal effects of Acts of Parliament, the doctrine of parliamentary sovereignty ultimately just commands that all constitutional actors give effect to Parliament's intentions - whatever they may be - when expressed in primary legislation. As Dicey contended, the substantive limits on Parliament's legislative supremacy, including on constitutional matters, are political rather than legal. The difference between what Parliament could command and what it should command is determined by the workings of a 'self-correcting majoritarian democracy' that is responsive to internal and external pressures. ${ }^{35}$

\section{(b) Completing the liberal paradigm}

The finding that, as an expression of Parliament's legislative supremacy, the doctrine of parliamentary sovereignty makes only a limited contribution to the discharging of the three minimum constitutional functions is revealing, albeit unsurprising. Legal scholars, including Dicey himself, have rightly long recognised that, in its uncodified form, the UK constitution does not rest on the doctrine of parliamentary sovereignty alone. ${ }^{36}$ Within the UK, the performance of minimum constitutional functions is guaranteed through a range of instruments and tools - including legislation and conventions. The fact that, as an expression of Parliament's legislative supremacy, the doctrine of parliamentary sovereignty does not itself satisfy citizen expectations in relation to the three minimum constitutional functions does not automatically condemn that doctrine (or, likewise, the UK constitution) as an illiberal aberration. This paper does not make that claim. It simply means that we must look beyond that doctrine to explore constitutional performance.

Adopting a broader approach to the assessment of minimum constitutional functions confirms that, as a matter of practice, though by no means exclusively, the UK constitution now relies on a highly developed statutory framework to meet the minimum demands of the modern liberal constitution. ${ }^{37}$ In other words, it demonstrates that Parliament has, to a considerable extent, legislated to align the UK constitution with the basic demands of the liberal paradigm. Parliament's contribution to the satisfaction of citizens' evolving expectations in relation to the three minimum constituting, legitimating and limiting functions is longstanding. It is also dynamic and progressive, reflecting both the emergence of liberal perspectives on state power as well as changing citizen expectations (and broader preferences) with respect to minimum constitutional functions.

With regard, first, to the constituting function, the Treaty of Union 1706 (also known as the Articles of Union), ratified by separate Acts of the English and Scottish Parliaments, ${ }^{38}$ provided for the establishment of Great Britain as a unitary state with one Parliament - the Parliament of Great Britain - under a single Monarch. ${ }^{39}$ The Act of Union with Ireland 1800 and, thereafter, the

\footnotetext{
${ }^{33}$ Gordon, above n 3, p 6. See also see M Elliot 'Parliamentary sovereignty and the new constitutional order' (2002) Legal Studies 340 at 368 .

${ }^{34}$ See also Dicey, above n 24, pp 39-40 and Gordon, above n 3, p 25. For judicial confirmation, see eg $R$ (on the application of Miller and Another) $v$ Secretary of State for Exiting the European Union [2017] UKSC 5, [2018] AC 61 at [137].

${ }^{35}$ Dicey, above n 24, p 76 and pp 82-83. The label 'self-correcting democracy' is adapted from Craig, above n 27.

${ }^{36}$ See also Loughlin, above n 12 , pp 30-31.

${ }^{37}$ See Bogdanor, above n 7 , and Laws, above n 2, p 5.

${ }^{38}$ Union with Scotland Act 1706 and Union with England Act 1706 respectively.

${ }^{39}$ Treaty of Union, arts 1-3.
} 
Anglo-Irish Treaty (ratified by the UK Parliament by the Irish Free State Constitution Act 1922) modified the territorial scope of the UK into its present form as the United Kingdom of Great Britain and Northern Ireland. The statutory framework addressing constituting functions now extends, of course, beyond the creation of the UK and its Parliament to establish the devolved administrations in Scotland, Wales and Northern Ireland, together with the differentiated framework of local government across the UK. ${ }^{40}$ The Scotland Act 1998, as amended, provides, for example, that there shall be a Scottish Parliament and Government as a permanent part of the UK's constitutional arrangements. ${ }^{41}$

The UK's judicial architecture also rests on statutory foundations. The Treaty of Union preserved the distinct institutional frameworks that applied within both England and Scotland prior to the unification of the two kingdoms. The judicial institutions within both nations of the Union have been subject to further statutory reform. The English judiciary, for instance, was radically restructured under the Judicature Acts of 1873 and 1875. These Acts fundamentally reformed, for the first time since the medieval period, the structure of the English judicial system, abolishing the pre-existing higher court system and creating in its place a new Supreme Court of Judicature (now renamed the Senior Courts of England and Wales) comprised of the High Court of Justice and the Court of Appeal. The process of statutory reform has continued thereafter both within and across the UK. Most significantly in recent years, the Constitutional Reform Act 2005 established the UK Supreme Court, replacing the Appellate Committee of the House of Lords.

Secondly, to address gaps in the constitution's legitimating functions, Parliament has repeatedly legislated to extend the franchise progressively, thereby grafting onto the doctrine of parliamentary sovereignty an increasingly strong link with popular sovereignty. ${ }^{42}$ This process of legislative reform began in earnest in the mid-nineteenth century, leading, most notably, to the recognition of equal suffrage under the Representation of the People (Equal Franchise) Act 1928. The abolition of the university seats and the lowering of the voting age to 18 thereafter further bolstered the legitimacy of the UK Parliament and, thereby, its claim to legislative supremacy under the doctrine of parliamentary sovereignty. ${ }^{43}$

Thirdly, Parliament has assumed a central role in discharging citizens' basic expectations in relation to the UK constitution's minimum limiting functions. The Human Rights Act 1998 (HRA 1998) now forms the centrepiece of its legislative efforts to ensure, as Wheare outlined, that government in the name of the people means limited government, free from the dangers of arbitrary rule. ${ }^{44}$ It achieves this by supercharging the pre-existing framework governing the protection of individual rights, which rested on the common law together with the specific protections guaranteed under the Bill of Rights 1689 (within England) and the Claim of Right 1689 (within Scotland). In more specific terms, the HRA 1998 empowers courts to scrutinise both executive and legislative acts for compliance with the international legal norms incorporated into UK law by virtue of Schedule 1 to that Act. ${ }^{45}$

The HRA 1998's major constitutional innovation in terms of limiting functions relates to the scrutiny of primary legislation - a significant gap prior to its enactment. The Act requires a ministerial

\footnotetext{
${ }^{40}$ On devolution, see eg Scotland Act 1998; Government of Wales Act 1998; Northern Ireland Act 1998; Government of Wales Act 2007, Northern Ireland Act 2009; Scotland Act 2012; the Wales Act 2014; Scotland Act 2016 and Wales Act 2017. On local government, see eg Local Government Act 1972; Local Government (Scotland) Act 1973; Local Government Wales Act 1994 and Local Government (Scotland) Act 1994.

${ }^{41}$ Scotland Act 1998, s 63A(1). For Wales, see Wales Act 2017, s 1(1).

${ }^{42}$ This process is not linear. For instance, through its use of referenda and establishment of devolved legislative bodies, respectively, Parliament has arguably legislated in a manner that potentially weakens its earlier interventions to bolster its legitimacy as the repository of popular sovereignty within the UK. See eg the Devolution Acts and European Union Referendum Act 2015.

${ }^{43}$ Representation of the People Acts of 1948 and 1969 respectively.

${ }^{44}$ Wheare, above n 6, p 137. On limiting functions, see also 'softer' legislative innovations, eg Freedom of Information Act 2000.

${ }^{45}$ For analysis, see A Kavanagh Constitutional Review under the Human Rights Act (Cambridge: Cambridge University Press, 2009).
} 
statement of conformity to accompany the introduction of new Bills to Parliament. ${ }^{46}$ More potently, it also empowers courts to scrutinise Acts of Parliament for compliance with the incorporated fundamental rights. ${ }^{47}$ Where that is not possible, judges may issue a declaration of incompatibility to alert Parliament to the conflict between the provisions of an Act of Parliament and specific human rights norms. ${ }^{48}$ That declaration has no impact on the continued validity of the legislation. ${ }^{49}$

\section{Constitutional functions and institutional responsibility}

As the previous section demonstrated, at the level of constitutional practice, primary legislation presently discharges most of the UK constitution's minimum constitutional functions in accordance with the demands of the liberal paradigm. The conclusion that Parliament has legislated, to a great extent, to 'complete' the UK constitution illuminates the distinct nature of the doctrine of parliamentary sovereignty's contribution to the performance of minimum constitutional functions: it is more facilitative than constitutive.

Hitherto, the scholarly focus on questions of ultimate authority or, likewise, the dynamics of political versus legal constitutionalism has tended to divert attention away from analysing the scope, depth and quality of the statutory framework enacted to discharge minimum constitutional functions. The analysis in the previous section redresses that imbalance. But this paper is not simply concerned with descriptive reconstruction. It seeks to identify and legitimate a framework of institutional responsibility that operates to ensure that, as the basis of a modern liberal state, the UK constitution continues to discharge its three minimum constitutional functions. With that aim in mind, this section defends the normative claim that principle should following practice; in other words, that it should fall to Parliament to exercise its legislative supremacy to ensure that the UK constitution discharges its minimum constituting, legitimating and limiting functions. It then outlines, in broad terms, two findings that attach to the recognition of that important institutional responsibility: the establishment of a positive obligation for Parliament to legislate to discharge its institutional responsibility, and a corresponding role for courts to intervene in instances of institutional failure.

Three reasons underpin the claim that, under the UK's atypical constitutional settlement, it should fall to Parliament to legislate to address gaps in the constitution's minimum constituting, legitimating and limiting functions. First, and least controversially, this follows for reasons of institutional capacity. ${ }^{50}$ Put simply, Parliament is uniquely placed among other rival actors to respond to the requirement to meet citizen expectations in relation to the performance of these minimum functions. Singularly among all constitutional actors, Parliament has a unique institutional capacity to address gaps in all three minimum functions. We cannot, for example, look to the judiciary to discharge constituting functions such as the establishment of the devolved administrations and/or frameworks of local government. ${ }^{51}$ These are fundamentally tasks for legislative bodies or, more commonly within liberal states, constituent assemblies. Equally, just as we may not look primarily to courts to establish the state and the basic institutions of government, so too must we turn to other institutions to address gaps in the UK constitution's legitimating functions. Courts are not the proper institutional fora to adjudicate on the composition of Parliament or, likewise, the method governing the appointment (ie election) of its members. They would also not claim such responsibilities.

Of course, few legal scholars would argue that rival institutions such as courts are particularly wellplaced to determine, for example, the composition of the UK state or the rules on elections to the

\footnotetext{
${ }^{46}$ HRA 1998, s 19. See D Feldman 'Parliamentary scrutiny of legislation and human rights' (2002) Public Law 323.

${ }^{47}$ HRA 1998, s 3 .

${ }^{48}$ HRA 1998, s 4 . On the relationship between that power and HRA 1998, s 3 see eg A Kavanagh 'Parliamentary intent, statutory interpretation and the Human Rights Act 1998' (2006) OJLS 179.

${ }^{49}$ HRA 1998, s 4(6).

${ }^{50}$ See generally P Yowell Constitutional Rights and Constitutional Design: Moral and Empirical Reasoning in Judicial Review (Oxford: Hart Publishing, 2013).

${ }^{51}$ See also Laws, who defends the distinctive institutional moralities of the legislature and the courts, respectively, as integral to maintaining 'constitutional balance': J Laws The Constitutional Balance (Oxford: Hart Publishing, 2021$)$ p 48.
} 
House of Commons. But this paper's defence of Parliament's responsibility to legislate on matter of minimum constitutional functioning goes beyond considerations of institutional capacity. It is supported, secondly, with reference to deeper issues of democratic legitimation. Specifically, it is argued that recognising Parliament's central role in the management of the UK constitution's minimum liberal functions enhances Parliament's (and, in turn, also the constitution's) democratic qualities. It does so - at least under the current statutory framework (eg the Representation of the People Acts) - by linking the discharging of minimum constitutional functions with deliberative majoritarian politics. ${ }^{52}$ Again, few legal scholars would take issue with that assertion. Indeed, a key argument supporting the codification of those aspects of the UK constitution that remain outside the framework of primary legislation (such as conventions) is that this would enhance its overall democratic legitimacy.

Finally, the argument that it is Parliament's responsibility to legislate to align the UK constitution with the liberal paradigm reflects the particular dynamics of that constitution under the doctrine of parliamentary sovereignty. A striking, atypical feature of the UK constitution under that doctrine is its positioning of Parliament at the apex of the constitution. Under rival models of constitutional design, the legislature is typically established - and expressly restrained by - the constitution, not positioned at its core. In addition, the defence of Parliament's institutional responsibility to lead on minimum constitutional functions is reinforced by the absence, pursuant to the doctrine of parliamentary sovereignty, of any formal distinction between ordinary and constitutional politics. Most other (codified) constitutional settlements distinguish between the day-to-day of ordinary politics and the management of minimum constitutional functions. In contrast to the position within the UK, changes to the basic structure of the state and its institutions of government, to electoral rights and procedures, or to the mechanisms and norms established to supervise public power are typically subject to extraordinary constitutional procedures distinct from ordinary legislative politics. ${ }^{53}$

Surveying the nature of the UK constitution in 1788, Madison drew express attention to these peculiar structural arrangements under the doctrine of parliamentary sovereignty. In the Federalist Papers, he noted that,

the authority of [the British] Parliament is transcendent and uncontrollable, as well with regard to the Constitution, as the ordinary objects of legislative provision. They [parliamentarians] have accordingly, in several instances, actually changed, by legislative acts, some of the most fundamental articles of the government. ${ }^{54}$

Recognising Parliament's responsibility to manage citizen expectations in relation to minimum constitutional functions in the above terms does not mean that Parliament must act - or that all aspects of the UK constitution should immediately be brought under statutory discipline. This paper does not make such a claim. Indeed, there may exist good reasons for aspects of minimum constitutional functioning to remain outside statutory frameworks. The use of conventions, for instance, is typically associated with greater flexibility. The decision to leave aspects of constitutional functioning outside statutory frameworks may also be a legitimate expression of democratic will: Parliament may consciously decide not to utilise its legislative supremacy to address specific matters. Finally, we must also acknowledge that, within all legal systems, there will always exist a body of non-codified rules and practices that supplement codified constitutional - or in the case of the UK, legislative - frameworks addressing minimum constitutional functions. ${ }^{55}$

The recognition of Parliament's institutional responsibility in relation to minimum constitutional functions does not challenge these dynamics. What it does do, however, is to establish a powerful

\footnotetext{
${ }^{52}$ See also Allan, above n 4, p 177 and Gordon, above n 3, p 6.

${ }^{53}$ Within the UK, this is true only to the limited extent that, at the level of practice, Parliament has adopted particular institutional procedures governing the scrutiny of certain types of legislation deemed constitutional in character. See eg $\mathrm{R}$ Hazell 'Time for a new convention: parliamentary scrutiny of constitutional bills 1997-2005' [2006] Public Law 247 at 248.

${ }^{54}$ A Hamilton et al Federalist Papers (London: Palgrave MacMillan, 2009) p 128. See also E Barendt An Introduction to Constitutional Law (Oxford: Clarendon, 1998) p 27.

${ }^{55}$ See eg M Foley The Silence of Constitutions (London: Routledge, 1989).
} 
framework to scrutinise Parliament's exercise of its legislative supremacy, at least in relation to matters of minimum constitutional functioning. That framework has two distinct components that speak, respectively, to the role of Parliament and to that of other constitutional actors, notably courts.

First, with regard to Parliament itself, the recognition of Parliament's institutional responsibility to lead on matters of minimum constitutional functioning directs attention to Parliament's positive obligations. Specifically, reinforcing constitutional practice (section 2, above), it mandates Parliament to legislate to ensure that the UK constitution effectively discharges its minimum constituting, legitimating and limiting functions under the liberal paradigm. ${ }^{56}$ In so doing, it illuminates an important 'power-generating' aspect of the doctrine of parliamentary sovereignty that requires Parliament to exercise its legislative supremacy to specific constitutional ends. ${ }^{57}$ The focus on positive obligations is largely missing from existing positivist accounts of the UK constitution. Legal scholars - including those presenting the strongest defences of the doctrine of parliamentary sovereignty - offer surprisingly little guidance regarding what Parliament actually ought to do with its legislative supremacy, ie to what ends its supremacy should be directed in a liberal democracy. ${ }^{58}$ They tend to focus instead on scrutinising what Parliament may not do with its legislative supremacy. As section 5 will demonstrate, the defence, in this paper, of Parliament's positive obligation to legislate to discharge minimum constitutional functions has important practical implications, including, for example, in relation to the control of prerogative powers.

Secondly, looking beyond Parliament, this paper's functional shift to considerations of institutional responsibility establishes a space for other institutional actors - notably, courts - to contribute to ensuring that the UK constitution discharges its three minimum liberal functions. In relation to courts, specifically, the institutional responsibility framework legitimates judicial intervention to address instances of institutional failure. It provides a normative basis for courts to intervene in instances where Parliament has failed to discharge its positive obligation to legislate to ensure the UK constitution performs its three minimum constitutional functions. Instances of constitutional failure on Parliament's part may take one of two forms. On the one hand, judicial intervention may target specific gaps in constitutional functions. This is a supplementary, supporting role, which recognises the potential for courts to contribute to the discharging of minimum constitutional functions in instances where, for instance, Parliament has not yet legislated to occupy the field. On the other hand, and more potently, courts may also legitimately 'push back' against Parliament in instances where it has legislated but its substantive choices are considered suspect under the liberal paradigm. This, of course, amounts to legitimating the judicial review of primary legislation.

Section 5 will return to consider the dual dynamics of judicial 'supplementation' and 'contestation', linking both to emerging developments in the jurisprudence. Before addressing that point, however, this paper attends to a final conceptual issue: the relationship between institutional responsibility and the doctrine of parliamentary sovereignty. The need to address that issue specifically arises as a direct result of the recognition, in the preceding analysis, of the potential for acts of judicial 'push back' against Parliament in defence of minimum constitutional functions. Legitimating the judicial review of primary legislation in those terms places the institutional responsibility framework in direct conflict with the orthodox view of parliamentary sovereignty as an expression of Parliament's legislative supremacy.

\section{Institutional responsibility and parliamentary sovereignty}

This paper theorises Parliament's positive obligation to lead on matters of minimum constitutional functioning as an external source of restraint on its legislative supremacy. This is not a rejection of its legislative supremacy and, consequently, the doctrine of parliamentary sovereignty itself.

\footnotetext{
${ }^{56}$ Allan gestures at this but only in abstract and in relation to a narrow conceptualisation of constitutional functions. See Allan, above n 4, p 33.

${ }^{57}$ Borrowing from M Loughlin Foundations of Public Law (Oxford: Oxford University Press, 2010) p 11.

${ }^{58}$ See, however, Gordon, above n 3, who argues that Parliament should use its legislative supremacy (under the 'manner and form' approach) to democracy-enhancing ends.
} 
However, it amounts to an important recognition that, to function as the keystone principle of a modern liberal democracy, that doctrine requires adjustment. From a functional perspective, the traditional Diceyan defence of a legally limitless scope for legislative activity under that doctrine is irreconcilable with the prescriptions of the modern liberal constitution. If the doctrine of parliamentary sovereignty is understood to empower Parliament to legislate, for example, to abolish universal suffrage or to erode basic liberties, its legitimacy as the cornerstone of the UK constitution would fall away. ${ }^{59}$ The recognition of political limits on its legislative supremacy - Dicey's vision of the self-correcting majoritarian democracy - does not change this. ${ }^{60}$ Of course, should Parliament legislate in such a manner (and we would hope not), the doctrine would survive as a principle of constitutional organisation. But the constitution that it organised would not be a liberal one. The doctrine of parliamentary sovereignty would transform (or revert) to being the foundation of an aristocratic or autocratic political order.

The claim that Parliament's legislative supremacy should, ultimately, be subject to external substantive restraint is endorsed in the existing legal scholarship. ${ }^{61}$ Allan, for instance, recognises similar normative limits,

Legislative supremacy is accepted on the basis that the UK Parliament 'legislates for a European liberal democracy' founded on the principles and traditions of the common law. ${ }^{62}$

However, this paper's institutional responsibility framework does not simply collapse into the common law constitutionalism defended by Allan, among others. It occupies an important space between existing accounts of the foundations of the UK constitution. On the one hand, the recognition of Parliament's positive obligation to legislate to secure minimum constitutional functions aligns with the views of those scholars who actively defend the status and legitimacy of parliamentary sovereignty as the cornerstone of the UK constitution. On the other hand, however, the legitimation of scope for judicial intervention in instances of institutional failure attends directly to the concerns of common law constitutional scholars, who criticise the doctrine's capacity to function as the keystone principle of constitutional organisation within a modern liberal state.

More profoundly, the institutional responsibility framework effects an important shift in conceptual thinking. It steers legal scholars away from a concern to identify (and justify) the UK constitution's ultimate source of authority. As Laws has argued, much of the legal scholarship remains engaged, in the positivist tradition, in a search for the constitution's 'master. ${ }^{63}$ Those defending parliamentary sovereignty vigorously defend the doctrine's status as a legitimate 'rule of recognition' or constitutional 'Grundnorm'. ${ }^{64}$ They do so appealing to its democratic virtues and by invoking 'manner and form' models, ${ }^{65}$ or theories of 'continuing', ${ }^{66}$ 'modified' or 'bi-polar ${ }^{67}$ legislative supremacy to overcome obstacles associated with the orthodox Diceyan account of the doctrine. In contrast, critics maintain that parliamentary sovereignty is simply no longer defensible as a principle of constitutional organisation within a modern liberal democracy. For them, it is the common law that must be considered the keystone of the UK constitution - its 'ultimate controlling factor' ${ }^{68}$

\footnotetext{
${ }^{59}$ See also Jowell, above n 32, at 578 and Allan, above n 4, p 140.

${ }^{60}$ See also Craig, above n 27, at 128, who points to weaknesses in Dicey's faith in representative democracy as an effective restraint on Parliament's legislative supremacy.

${ }^{61}$ See here especially Allan, above $\mathrm{n} 4$, who invokes the rule of law as a substantive restraint on legislative supremacy.

${ }^{62}$ Ibid, p 139.

${ }^{63}$ Laws, above n 2, p 28.

${ }^{64}$ On parliamentary sovereignty as a rule of recognition, see also Miller (No 1), above n 34, at [60].

${ }^{65}$ See WI Jennings The Law and the Constitution (London: University of London Press, $5^{\text {th }}$ edn, 1959), RFV Heuston Essays in Constitutional Law (Stevens and Sons, $2^{\text {nd }}$ edn, 1964), J Goldsworthy Parliamentary Sovereignty: Contemporary Debates (Cambridge: Cambridge University Press, 2010) and Gordon, above n 3.

${ }^{66}$ See Young, above n 3.

${ }^{67}$ See S Sedley 'Human rights a twenty-first century agenda' [1995] Public Law 386 and AL Young Democratic Dialogue and the Constitution (Oxford: Oxford University Press, 2017).

${ }^{68}$ Lord Hope in Jackson $v$ Attorney-General, above n 4, at [107].
} 
The functionalist framework on institutional responsibility breaks with this dynamic. It shifts the spotlight from discussing authority (the search for the constitution's ultimate 'master') to scrutinising the performance of constitutional functions. Pushing things further, the primacy that framework attaches to constitutional functions, rather than positivist concerns with the determination of ultimate authority, also challenges the traditional dichotomy between normative interpretations of the UK constitution as a paragon of political or legal constitutionalism. ${ }^{69}$

Rather than fixating on questions of authority (or, relatedly, the distinctions between models of constitutional design), the institutional responsibility framework directs us to the quality of the framework that is being constructed: the liberal constitution. Of course, to defend this shift in perspective is not to ignore normative positions on the relative strengths and weaknesses of the political versus legal modes of constitutional construction. What the institutional responsibility model does do, however, is to integrate this discussion into an alternative conceptual framework that engages with, but is not driven by, a concern to identify the ultimate political or legal nature of the UK constitution. The primacy that the framework attaches to the virtues of constitutional construction by legislative decision-making admittedly aligns with the normative claims of political constitutionalism. But it is not blinded by them. As outlined in section 3, instances of institutional failure on Parliament's part empower the courts to intervene in a manner that speaks to the concerns of legal constitutionalists. This includes safeguarding the minimum demands of the liberal constitution through acts of judicial supplementation and, more provocatively, contestation (see, further, section 5(a) below).

A final distinguishing feature speaks to matters of scope. Specifically, it is important to emphasise that the institutional responsibility framework operates to enlarge the range of substantive concerns presently addressed in debates about the integrity of the UK constitution. As a source of external normative restraint on the exercise of Parliament's legislative supremacy, that framework takes us beyond the dominant concern - particularly among common law constitutionalists - with safeguarding the rule of law. It directs attention instead to a richer set of minimum constituting, legitimating and limiting functions that, as this paper has argued (section 1, above), citizens may legitimately expect constitutions to perform in liberal democracies regardless of their form.

\section{Understanding the UK constitution: the role of institutional responsibility}

This section explores the practical implications of the institutional responsibility framework advanced in this paper. That framework makes three distinct contributions to the study of the UK constitution. First, it enables us to make better sense of the emerging jurisprudence gesturing at the judicial review of primary legislation; secondly, it offers a richer and more compelling account of the place of 'constitutional statutes' within the UK constitution; and thirdly, it identifies specific deficiencies in Parliament's legislative output on matters of minimum constitutional functioning. The first and second contributions unlock practical insights into two constitutional conundrums; the third moves beyond existing debates to highlight new instances of constitutional tension.

\section{(a) Institutional responsibility and the courts: supplementation and contestation}

The first contribution that the institutional responsibility framework makes is to enhance our understanding of the judicial role under the UK constitution. Specifically, that framework legitimates the courts' contribution to the satisfaction of citizen expectations in relation to minimum constitutional functions through acts of judicial supplementation and, more provocatively, judicial contestation (or 'push back').

Recalling the discussion in section 3 above, the first of these dynamics - supplementation - references judicial intervention to address gaps in minimum constitutional functioning. Familiar examples include the courts' use of statutory interpretation to safeguard the rule of law in the application of abstract legislative frameworks to specific legal problems. Legal scholars, including those defending

\footnotetext{
${ }^{69}$ Young makes a similar claim in her defence of dialogue theory. See Young, above n 67, p 32.
} 
parliamentary sovereignty, ${ }^{70}$ widely acknowledge and defend this important supplementary judicial role, albeit without reference to institutional responsibility. For Allan, statutory interpretation within the liberal state is a morally-engaged activity that demands that the courts read compliance with the rule of law into Parliament's legislative choices. ${ }^{71}$ Similarly, according to Laws,

[ $\mathrm{t}$ ] he requirement of independent statutory interpretation by the judges applying the principles of the common law is not a desirable extra, nor the fifth wheel of the coach, it is integral to the constitutional balance. ${ }^{72}$

But the dynamics of supplementation extend much further than statutory interpretation. They also capture - and justify - judicial interventions to fill more systemic gaps in the UK constitution's minimum functions. Prominent examples include the courts' development of the modern framework of judicial review ${ }^{73}$ and their continued interventions to control prerogative powers that remain, as yet, undisciplined by Parliament. ${ }^{74}$ Both sets of examples operate to reinforce the constitution's important limiting function in the absence of comprehensive legislative frameworks.

More potently, the institutional responsibility framework explicitly sanctions acts of judicial contestation: the judicial review of primary legislation to safeguard the minimum requirements of the liberal constitution. Specifically, it provides a normative basis for courts to 'push back' against Parliament in instances where that institution has exercised its legislative supremacy, but its choices are highly suspect against the liberal paradigm. Of course, it is reasonable to expect that Parliament will ordinarily effectively discharge its positive obligation under the institutional responsibility framework to legislate to address gaps in minimum constitutional functions. However, we cannot escape acknowledging that, under the doctrine of parliamentary sovereignty, it remains open to Parliament to legislate expressly to undermine the UK constitution's basic legitimating and limiting functions. ${ }^{75}$ Parliament could legislate, for instance, severely to curtail the franchise or abolish either the courts or, more narrowly, the institution of judicial review. In such cases, the institutional responsibility framework fully supports judicial intervention to contest - and, ultimately, invalidate Parliament's legislative choices in defence of the liberal paradigm.

In a series of high-profile judgments, senior figures within the judiciary have alluded to the legitimacy of the courts striking down Acts of Parliament that sought, for instance, to oust the jurisdiction of the ordinary courts or to abolish the franchise. ${ }^{76}$ Initiating that discussion, Lord Steyn noted obiter in Jackson that,

[i]n exceptional circumstances involving an attempt to abolish judicial review or the ordinary role of the courts, the Appellate Committee of the House of Lords or a new Supreme Court may have to consider whether this is a constitutional fundamental which even a sovereign Parliament acting at the behest of a complaisant House of Commons cannot abolish. ${ }^{77}$

\footnotetext{
${ }^{70}$ Ibid. See also Dicey, above n 24, p 273, who defended the subjugation of Parliament's will to judicial interpretation through the common law as means to secure the rule of law.

${ }^{71}$ Allan, above n 4, p 9.

${ }^{72}$ Laws, above n 2, p 26. For judicial support, see eg Lord Steyn in $R v$ Secretary for the Home Department, ex $p$ Pierson [1998] AC 539 at 587.

${ }^{73}$ See eg Padfield v Minister for Agriculture, Fisheries and Food [1968] AC 997; Council of Civil Service Unions \& Others $v$ Minister for the Civil Service [1985] AC 374; $R v$ Secretary of State for the Home Department, ex $p$ Daly [2001] UKHL 26, [2001] 2 AC 532; and R (on the application of UNISON) $v$ Lord Chancellor [2017] UKSC 51, [2017] 3 WLR 409.

${ }^{74}$ Miller (No 1), above n 34, at [137] and Miller/Cherry, above n 24, at [41].

${ }^{75}$ For examples of suspect legislative proposals, see eg cl 47 of the United Kingdom Internal Market Bill 2019-2020 and cl 2 of the Overseas Operations (Service Personnel and Veterans) Bill 2019-21.

${ }^{76}$ See Lord Steyn in Jackson, above n 4, at [102]. See, thereafter, Lord Hope in AXA General Insurance Ltd, above n 8, at [50]-[51]. See also Lord Mance and Lord Neuberger in HS2 Action Alliance Ltd, above n 8, at [207] and Lord Carnwath in Privacy International, above n 8 , at [123] and at [131].

${ }^{77}$ Jackson, above n 4, at [102].
} 
Presently, those defending the legitimacy of empowering courts to scrutinise Parliament's legislative choices do so primarily by juxtaposing parliamentary sovereignty with the rule of law as a rival common law principle of constitutional organisation. Others manage the implications of the courts' obiter remarks by continuing to recognise Parliament's ultimate legislative supremacy whilst appealing, at the same time, to its political morality as a source of practical restraint on illiberal legislative ambitions. ${ }^{78}$ Indeed, for Marshall, that Parliament should not use its legislative supremacy in an oppressive or tyrannical manner constitutes 'the most obvious and undisputed convention' of the UK constitutional order. $^{79}$

The institutional responsibility framework invites us to think differently about the emerging jurisprudence gesturing at the judicial review of primary legislation in defence of the rule of law. That framework does not require the abandonment of parliamentary sovereignty as the keystone principle of constitutional organisation or, alternatively, require the placing of trust in Parliament's internal morality to avoid illiberal outcomes. ${ }^{80}$ Rather, as the discussion of judicial contestation outlines, it establishes a robust framework to legitimate the judicial review of Acts of Parliament in instances where Parliament is judged to have failed to discharge its responsibility to legislate to align the UK constitution with the minimum requirements of the liberal state. ${ }^{81}$ As the jurisprudence rightly indicates, within a functioning liberal democracy, the circumstances prompting such intervention should arise only exceptionally - if at all. But when they do arise, the institutional responsibility framework leaves no doubt that it is legitimate for the courts to intervene.

Justifying a role for courts to push back against Parliament in the above terms does not, of course, unlock neat answers to questions on minimum constitutional performance. Parliament and the courts may legitimately disagree about the threshold for safeguarding the constitution's minimum liberal functions. The institutional responsibility framework advanced in this paper does not resolve that issue. The task of determining, for example, whether the UK constitution effectively protects the rule of law in any given scenario sidesteps positivist arguments about ultimate political authority. But it leaves open space for subjective disagreement between Parliament and the courts in relation to the minimum demands of the liberal paradigm. This is no bad thing. Dialogue theorists and pluralist scholars (who tend also to eschew discussion of ultimate authority) see particular virtue in such conflict - at least in instances where the legislature is afforded sufficient opportunity to respond to adverse judicial decisions. ${ }^{82}$

\section{(b) Institutional responsibility and constitutional statutes}

The language of constitutional statutes entered into play in Thoburn. Here, Laws LJ defined a constitutional statute as one that either 'conditions the legal relationship between citizen and state in some general, overarching manner' or 'diminishes the scope of what we would now regard as fundamental constitutional rights. ${ }^{83}$ The examples cited include Magna Carta; the Bill of Rights 1689; the Union with Scotland Act 1706; the Representation of the People Acts 1832, 1867 and 1884; the HRA 1998 and the Devolution Acts.

Presently, discussion of constitutional statutes and their place within the UK constitution is again approached, in the positivist tradition, with reference to questions of ultimate authority. ${ }^{84}$ The challenge for those recognising the existence of constitutional statutes (or, analogously, 'constitutional instruments') $)^{85}$ is essentially to explain how these statutes fit with the traditional view of

\footnotetext{
${ }^{78}$ See eg Laws, above $\mathrm{n} 2$, p 28. See also, referencing constitutional rather than simply political morality, M Elliot 'Parliamentary sovereignty in a changing constitutional landscape' in Jowell and O'Cinneide, above n 21, p 57.

${ }^{79} \mathrm{G}$ Marshall Constitutional Conventions (Oxford: Clarendon Press, 1984) p 8.

${ }^{80}$ On the latter, see also Dicey, above n 24 , pp 76-78 and pp 80-81.

${ }^{81}$ Note: for reasons of institutional capacity and democratic legitimacy, acts of judicial contestation (and, by analogy, judicial supplementation) are unlikely to address the UK constitution's constituting functions. See section 3 above.

${ }^{82}$ See Young, above n 67.

${ }^{83}$ Laws LJ in Thoburn $v$ Sunderland City Council [2002] EWHC 195 (Admin), [2002] 3 WLR 247 at [62]

${ }^{84}$ See eg F Ahmed and A Perry 'The quasi-entrenchment of constitutional statutes' (2014) 73(3) CLJ 514.

${ }^{85}$ Lord Mance and Lord Neuberger in HS2 Action Alliance Ltd, above n 8, at [207]. See also subsequently, $R$ (on the application of Miller and Another), above n 34, at [67] referencing the 'constitutional character' of the European Communities Act 1972.
} 
Parliament's legislative supremacy. Typically, those defending the place of constitutional statutes within the UK's constitutional framework argue that such statutes are not subject to the ordinary application of the doctrine of implied repeal. ${ }^{86}$ Laws LJ pioneered that approach in Thoburn,

[o]rdinary statutes may be impliedly repealed. Constitutional statutes may not... A constitutional statute can only be repealed, or amended in a way which significantly affects its provisions touching fundamental rights or otherwise the relation between citizen and State, by unambiguous words on the face of the later statute. ${ }^{87}$

The adherence to parliamentary sovereignty as a statement on Parliament's legislative supremacy has distorted discussion of constitutional statutes within the UK constitution. It focuses attention narrowly on analysis of the legal effects of recognising specific Acts of Parliament including Magna Carta, the Devolution Acts and the HRA 1998 as 'constitutional statutes'. For legal scholars, the fundamental question remains at all times: what does the recognition of specific Acts of Parliament as 'constitutional statutes' mean for the scope of Parliament's legislative supremacy?

The institutional responsibility framework recasts that approach. It links discussion of constitutional statutes with questions of constitutional functioning rather than positivist concerns with ultimate authority. ${ }^{88}$ From that perspective, the principal factor differentiating 'constitutional' from 'ordinary' legislation operates at the level of description. Put simply, the label 'constitutional statute' references legislation that Parliament has enacted - pursuant to its institutional responsibility - to discharge the UK constitution's basic constituting, legitimating and limiting functions. ${ }^{89}$ It is this link to constitutional functioning that distinguishes, for example, the Acts of Union or the HRA 1998 from, say, the Gambling Act 2005. We have already encountered, in section 2 above, the detailed body of primary legislation that Parliament has enacted to ensure the UK constitution satisfies citizen expectations in relation to minimum constitutional functions. The adjective 'constitutional' may be attached to this body of legislation as a descriptive marker vis-à-vis ordinary Acts of Parliament that do not discharge constitutional functions.

Linking constitutional statutes to the performance of minimum constitutional functions in this manner offers a more principled account of the place of such instruments within the UK constitution. The identification of constitutional statutes is no longer simply a matter for intuitive judicial determination. It is based on a set of functional features with which both Parliament and the courts may engage.

Of course, shifting the focus from legal effects to constitutional functions does not eliminate the potential for conflict between - in their new descriptive form - 'constitutional' and 'ordinary' statutes. ${ }^{90}$ But the institutional responsibility framework offers a potential solution here too. That framework directs the courts to approach instances of conflict between ordinary and constitutional statutes (or between constitutional statutes inter se) ${ }^{91}$ as problems of constitutional functioning that should be resolved through statutory interpretation. It does not, in contrast, invite (or, moreover, require) the courts to engage further in a quest to reconcile constitutional statutes with the recognition of Parliament's legislative supremacy as a 'rule of recognition'. Accordingly, the primary task for the court in instances of conflict becomes one of identifying, through ordinary statutory interpretation,

\footnotetext{
${ }^{86}$ See also Lord Hope in $H v$ Lord Advocate [2012] UKSC 24, [2013] 1 AC 413 at [30] (with Lady Hale and Lord Kerr agreeing) and Beatson $\mathrm{J}$ in $R$ (on the application of Brynmawr Foundation School Governors) $v$ Welsh Ministers [2011] EWHC 519 (Admin).

${ }^{87}$ See Laws LJ in Thoburn, above $\mathrm{n} 83$, at [63].

${ }^{88}$ For an alternative contextual re-conceptualisation, see Psygkas, above $\mathrm{n} 7$.

${ }^{89}$ Note: the designation 'constitutional' does not necessarily attach to statutes in their entirety, rather only to those provisions that discharge minimum constitutional functions. See also Psygkas, above n 7, at 465

${ }^{90}$ See eg the Welsh Government's challenge to the legality of the Internal Market Act 2020 in The Counsel General for Wales $v$ Secretary of State for Business, Energy and Industrial Strategy [2021] EWHC 950 (Admin).

${ }^{91}$ See eg HS2 Action Alliance Ltd, above n 8.
} 
Parliament's statements on specific matters of constitutional functioning and giving those statements effect.

This new approach is no panacea. It also does not eradicate entirely discussion of legal effects under current approaches to theorising constitutional statutes. But it does make it easier to resolve many apparent instances of conflict between statutes through a principled framework that looks beyond implied repeal. In summary, the institutional responsibility framework establishes a strong presumption that constitutional functions remain unaltered by the provisions of ordinary statutes. Put another way, ordinary legislative provisions should be presumed not to alter the provisions of constitutional statutes, but instead to yield to the latter by default. Accordingly, in instances of conflict with ordinary statutes - ie those not addressing minimum constituting, legitimating and limiting functions - the task for the court is to interpret ordinary statutes in conformity with the demands of constitutional statutes. In relation to conflicts between constitutional statutes, the court's role is to give effect to Parliament's most recent statements on the relevant constitutional function. ${ }^{92}$

This is arguably what Laws LJ was ultimately gesturing at in Thoburn when introducing the constitutional statutes designation to resolve an apparent conflict between s 2(2) of the European Communities Act 1972 and s 1 of the Weights and Measures Act 1985. Reframed as a problem of constitutional functioning, there was no question of the 1985 Act - as an ordinary Act of Parliament - having altered the relationship between UK and EU law under the 1972 Act. As a constitutional statute discharging constituting functions, the 1972 Act outlined the terms governing the reception of EU law within the United Kingdom. Three further constitutional statutes - the EUA 2011 and, thereafter, the EU (Withdrawal) Act 2018 and EU (Withdrawal Agreement) Act 2020 have subsequently altered those terms. But the Weights and Measures Act 1985 certainly did not. There was no question, therefore, of the 1985 Act having impliedly repealed s 2(2) of the 1972 Act. ${ }^{93}$ The same reasoning may also be invoked to neutralise the alleged conflict in Factortame on which Laws LJ expressly draws in Thoburn - between the 1972 Act and the Merchant Shipping Act $1988 .^{94}$ The latter Act, as an ordinary statute, yielded to the 1972 Act as a constitutional statute that (at the material time) outlined the status of EU law within the UK.

Abandoning discussion of legislative supremacy as a 'rule of recognition' or constitutional 'Grundnorm' in favour of attending to considerations of constitutional functioning strengthens the case for acknowledging the 'quasi-entrenchment" ${ }^{95}$ of constitutional statutes. As Ahmed and Perry argue, the jurisprudence presently 'lacks a sound theoretical basis' to defend that claim. ${ }^{96}$ The institutional responsibility framework offers a solution to that deficiency. In addition, that framework's focus on accentuating constitutional functions injects greater precision into the definition of constitutional statutes. ${ }^{97}$ As noted above, in Thoburn, Laws LJ defined these rather abstractly as Acts of Parliament that condition the 'legal relationship between citizen and state in some general, overarching manner' or '[diminish] the scope of what we would now regard as fundamental constitutional rights'. Subsequent judgments have added additional colour, but the definition remains rather unrefined, nonetheless. ${ }^{98}$ The institutional responsibility framework, with its focus on minimum constitutional functions within liberal states, offers a much more coherent conceptual approach. It circumscribes 'constitutional statutes' more meaningfully as those enacted to discharge the liberal constitution's three minimum constituting, legitimating and limiting functions. ${ }^{99}$

\footnotetext{
${ }^{92}$ Contrast eg Elliot, who defends an approach based on 'relative fundamentality': M Elliot 'Constitutional legislation, European union and the nature of the United Kingdom's contemporary constitution' (2014) 10 ECLR 379 at 387.

${ }^{93}$ Ibid, at 387.

${ }^{94}$ Factortame (No 1) [1990] 2 AC 85.

${ }^{95}$ This term is borrowed from Ahmed and Perry, above $\mathrm{n} 84$.

${ }^{96}$ Ibid, at 515 .

${ }^{97}$ For criticism on that point, see D Feldman 'The nature and significance of “constitutional” legislation' (2013) 129 LQR 343.

${ }^{98}$ See eg Lord Hope on the Scotland Act 1998 in H v Lord Advocate, above n 86, at [30].

${ }^{99}$ See here similarly Feldman, above n 98 , at 387. For an indicative list of constitutional statutes, see section 2(b) above.
} 


\section{(c) Institutional responsibility and Parliament}

As section 3 outlined, the institutional responsibility framework imposes an important positive obligation on Parliament. It mandates Parliament to exercise its legislative supremacy to particular constitutional ends; specifically, it directs Parliament to legislate to ensure the UK constitution discharges the liberal constitution's minimum constituting, legitimating and limiting functions. But what broader, practical conclusions should we draw from the recognition of that important obligation?

In the first instance, recognising Parliament's positive obligation under the institutional responsibility framework may be employed to diagnose specific deficiencies in institutional functioning. The existence, at the level of constitutional practice, of an established framework of 'constitutional statutes' (as redefined above) enacted to discharge the UK constitution's minimum constitutional functions (section 2, above) does not foreclose such enquiry. Gaps and tensions remain. This section foregrounds one example: Parliament's failure to discipline the prerogative power to prorogue Parliament. This high-profile illustration is particularly instructive. It captures, rather neatly, the dynamics of the institutional responsibility framework at play in relation to safeguarding the UK constitution's limiting functions.

In Miller/Cherry, the UKSC ruled unanimously that,

a decision to prorogue Parliament (or to advise the monarch to prorogue Parliament) will be unlawful if the prorogation has the effect of frustrating or preventing, without reasonable justification, the ability of Parliament to carry out its constitutional functions as a legislature and as the body responsible for the supervision of the executive. ${ }^{100}$

The Supreme Court justified its conclusion with reference to the doctrine of parliamentary sovereignty and what it framed as a complementary constitutional principle of parliamentary accountability. ${ }^{101}$

From an institutional responsibility perspective, the Court's imposition of limits on the prerogative power to prorogue Parliament may be interpreted - and, moreover, legitimated - as an important act of judicial supplementation (section 5(a), above). It addressed a key gap in the UK constitution's limiting function to which Parliament had failed to attend. As the UKSC recognised, absent circumscribed limits (which Parliament had not provided), the power to prorogue Parliament was open to potential executive abuse. It furnished an unscrupulous executive with a power to shut down - at least temporarily - the ordinary scrutiny functions that Parliament performs vis-à-vis the executive. ${ }^{102}$ As the Court unanimously concluded, this is fundamentally at odds with the minimum demands of a liberal constitution. ${ }^{103}$ Indeed, it is extremely difficult to see any virtue in counterfactual arguments that the executive should, in a modern liberal democracy, continue enjoy an unconstrained power temporarily to suspend parliamentary scrutiny of its activities.

As an act of constitutional supplementation, the UKSC ruling marked an important intervention in defence of the UK constitution's functioning as the foundation of a modern liberal state. But the story does not end with the Court's decision. The focus must now return to Parliament and its positive obligation to legislate in response to the Court's diagnoses of an important gap in the UK constitution's limiting functions. As the source of that obligation, the institutional responsibility framework does not necessarily require Parliament simply to replicate the UKSC's conclusions in legislative form. But it does demand that Parliament engage with the illiberal mischief that the Court unmasked in its ruling. At the time of writing, Parliament's response on that point remains distinctly underwhelming. Thus far, there appear no proposals for a legislative response to address the concerns unmasked by the

\footnotetext{
${ }^{100}$ Miller/Cherry, above n 24, at [50].

${ }^{101}$ Ibid, at [41]-[48].

${ }^{102}$ Ibid, at [2].

${ }^{103}$ See also eg P Craig 'The Supreme Court, prorogation and constitutional principle' (2020) Public Law 248. The UKSC's decision has also attracted strong criticism from other perspectives, see eg T Endicott 'Making constitutional principles into laws' (2020) 136 LQR 175.
} 
UKSC in Miller/Cherry. Indeed with reference to disciplining prerogative powers more broadly, the present Government seems set on moving in the opposite direction; for example, its Draft Fixedterm Parliaments Act 2011 Repeal Bill proposes to restore the prerogative power to dissolve Parliament as this existed prior to the enactment of the Fixed-terms Parliament Act 2011. ${ }^{104}$

The argument that Parliament should legislate to address gaps in minimum constitutional functions, such as those exposed by the UKSC in Miller/Cherry, raises further complexities owing, in particular, to the fusion of executive and legislative authority under the UK constitution. That fusion, which arises as a result of the UK's constituency-based first-past-the-post electoral system, positions Parliament's institutional responsibility in a relationship of co-dependency with the preferences of the majority government of the day. The impact of that relationship on the performance of Parliament's institutional responsibility is, of course, most pronounced in instances, such as the prerogative powers example, where the demands of the liberal constitution pull in different directions to executive preferences.

The institutional responsibility framework does not provide easy answers to the challenges of executive dominance in Parliament. However, it does provide a framework to structure relationships and, importantly, incentivise majority governments to work constructively with Parliament to diagnose and address outstanding gaps in minimum constitutional functions, including in relation to prerogative powers. The degree to which majority governments are able to moderate self-interest and work effectively with Parliament to do so will, in turn, determine the scope for judicial intervention. Should, for example, the executive stubbornly thwart attempts to legislate to address outstanding gaps in the UK constitution, such behaviour will only enlarge the scope for the courts to exert influence on matters of minimum constitutional functioning through future acts of judicial supplementation and/or contestation (section 5(a) above). ${ }^{105}$ The message to strong majority governments under the institutional responsibility framework is therefore clear: work constructively with Parliament to secure minimum constitutional functions or live with the potential consequences of leaving the management of aspects of those functions to the courts.

In a second, separate line of enquiry, the institutional responsibility framework also challenges broader macro-level trends in Parliament's institutional behaviour. In particular, it raises questions about the legitimacy of Parliament's longstanding efforts to preserve the integrity of its legislative supremacy when legislating to ensure the UK constitution satisfies minimum liberal demands. Consider, for example, the extent to which Parliament sought to prioritise the preservation of its legislative supremacy when establishing judicial review powers under the HRA $1998 .{ }^{106}$ Sections 3 and 4 of that Act were designed to subjugate the judicial contribution to safeguarding the protection of fundamental rights to legislative control. Indeed, pursuant to s 4(6), the courts are expressly precluded from invaliding Acts of Parliament that cannot be read in conformity with the provisions of the European Convention on Human Rights incorporated into UK law under Schedule 1 to the HRA 1998.

The institutional responsibility framework casts doubt on the legitimacy of Parliament's efforts to defend the integrity of its legislative supremacy in such absolute terms. The fact that Parliament expresses its desire to preserve its legislative supremacy in absolute terms when enacting constitutional statutes (as redefined by this paper) cannot not be taken as conclusive. From a functionalist perspective, the effectiveness of any statements to that effect - including those set out in constitutional statutes such as the HRA 1998 - remains ultimately conditional on the quality of Parliament's substantive choices in relation to minimum constitutional functions. Accordingly, it is no defence for Parliament simply to point to an Act of Parliament such as the HRA 1998 expressly precluding the

\footnotetext{
${ }^{104}$ Draft Fixed-term Parliaments Act 2011 Repeal Bill, published 1 December 2020 and available at https://assets.publishing.service.gov.uk/government/uploads/system/uploads/attachment_data/file/940027/Draft-Fixed-term-Parliaments-Act-RepealBill.pdf (last accessed 2 June 2021).

${ }^{105}$ Note: for reasons of institutional capacity and democratic legitimacy, acts of judicial contestation (and, by analogy, judicial supplementation) are unlikely to address the UK constitution's constituting functions. See section 3 above.

${ }^{106}$ See Rights Brought Home: The Human Rights Bill (1997) CM 3782, p 10. See also, analogously, s 28 of the Scotland Act 1998. For discussion, see Elliot, above n 33, at 346-356.
} 
judicial review of primary legislation to defeat arguments advanced before the courts that it has failed to discharge its institutional responsibility in specific instances. The space for courts to engage in exceptional acts of 'judicial contestation' (section 5(a), above) to safeguard the constitution's legitimating and limiting functions arises independently of Parliament's desire to preserve the integrity of its legislative supremacy, including under the HRA 1998.

This does not, of course, negate the importance of constitutional statutes such as the HRA 1998, which, as already noted (section 2, above), make important contributions to the routine operation of the UK constitution as the foundation of a modern liberal state. But it does make clear that Parliament's intentions do not singularly define the boundaries for judicial intervention to review Acts of Parliaments that undermine the constitution's legitimating and limiting functions. Should, for example, Parliament legislate severely to restrict the franchise or, similarly, to abolish judicial review, the institutional responsibility framework ultimately empowers the courts to intervene to safeguard the minimum demands of the UK constitution as the cornerstone of a modern liberal state. As this paper has argued, the competence of the courts to do so is not grounded in arguments about ultimate authority (specifically: common law constitutionalism). Rather, it is tied, functionally, to the delivery of citizens' minimum expectations within modern liberal states.

\section{Conclusion}

Whether discussing constitutional statutes, human rights, judicial review or the doctrine of parliamentary sovereignty, legal scholarship on the UK constitution displays a tendency to prioritise questions of ultimate authority over those of constitutional functioning. This, in turn, is linked with broader explanatory and normative discussion of the constitution's underlying nature as a paradigm of political or legal constitutionalism. The preoccupation with searching for the UK constitution's 'ultimate master' is entirely logical. A powerful claim to final authority is, of course, engineered into the traditional view of the doctrine of parliamentary sovereignty as a statement on Parliament's legislative supremacy. But, as this paper has revealed, placing too much emphasis on the identification and management of constitutional authority has a distorting effect on our appreciation of the UK constitution as an embodiment of the liberal social construct. At best, it distracts attention from assessing its performing of the minimum demands that citizens may legitimately expect all constitutions to perform within modern liberal states. At worst, it risks displacing the scrutiny of constitutional functions entirely.

The functional analysis this paper advances does not disregard normative arguments about ultimate constitutional authority. Nor does it eliminate tensions between Parliament and the courts or, similarly, resolve concerns about executive dominance. What is does do, however, is transform these arguments and concerns into more complex dynamics addressing the attribution of institutional responsibility to deliver the range of fundamental constitutional functions that this paper has presented as minimum requirements under the liberal paradigm.

Within the UK, Parliament carries the institutional responsibility to ensure that the constitution remains aligned with citizens' expectations on matters of minimum constitutional functioning. That responsibility arises for three reasons: institutional capacity, democratic legitimation and affinity with the keystone doctrine of parliamentary sovereignty. The recognition of Parliament's institutional responsibility translates into a positive obligation requiring it to legislate to ensure the UK constitution discharges its minimum 'constituting', 'legitimating' and 'limiting' functions under the liberal paradigm. Importantly, it also establishes a corresponding basis to legitimate judicial intervention in instances of institutional failure; in other words, where Parliament has failed to attend to those functions. To the extent that this engages acts of judicial contestation (ie 'push back' against Parliament), we would expect intervention by the courts to be exceptional, not routine. Historically at least, Parliament tends to 'self-correct' politically to avert direct conflict with the courts on issues of minimum constitutional functioning. ${ }^{107}$

\footnotetext{
${ }^{107}$ See eg the Blair Government's withdrawal of the ouster clause included in the Asylum and Immigration (Treatment of Claimants) Bill 2003 in response to strong opposition from within (but also beyond) Parliament.
} 
In broader terms, the institutional responsibility framework enhances our understanding of the contemporary UK constitution both descriptively and normatively. It adds important value to existing perspectives in several respects: by expanding discussion of constitutional functions beyond the rule of law (the limiting function); by explicitly exposing the depth of the statutory foundations of the UK constitution; by injecting new meaning into 'constitutional statutes' and, finally, by theorising the role of the courts in the management of the UK constitution with reference to the concepts of judicial supplementation and judicial contestation. Most significantly, however, the institutional responsibility framework ultimately draws attention back to Parliament and its positive obligation to legislate to align the UK constitution with the minimum demands of the liberal paradigm. A review of constitutional practice (section 2) demonstrates that Parliament has, to a great extent, legislated effectively to discharge the UK constitution's three minimum 'constituting', 'legitimating', and 'limiting' functions. But significant gaps and tensions remain.

The conclusion we reach at the close of this analysis is clear: Parliament ought to work harder to discharge its positive obligation to legislate to secure the minimum demands of the liberal constitution. This does not just require targeted responses to address, for example, its failure to discipline executive prerogative powers or, likewise, its attempts to prioritise protecting the integrity of its legislative supremacy over the performance of minimum constitutional functions. More fundamentally, it challenges Parliament (and legal scholars) to think much more coherently and holistically about the overall constitutional framework that, under the UK's atypical constitutional settlement, Parliament is institutionally responsible for delivering to citizens.

Cite this article: Horsley T (2022). Constitutional functions and institutional responsibility: a functional analysis of the UK constitution. Legal Studies 42, 99-119. https://doi.org/10.1017/lst.2021.32 